\title{
PEMBUATAN KECAP IKAN DARI IKAN BULU AYAM (Coilia dussumieri) DENGAN METODE HIDROLISIS ENZIMATIS MENGGUNAKAN SARI NANAS
}

\section{FISH SAUCE FROM BULU AYAM FISH (Coilia dussumieri) WITH ENZYMATIC HYDROLYSIS METHOD USING PINEAPPLE JUICE}

\author{
Kurnia Sada Harahap ${ }^{1 *}$, Apri Mujiyanti ${ }^{1}$, Lia Novita Sari ${ }^{1}$ \\ ${ }^{1}$ Program Studi Pengolahan Hasil laut, Politeknik Kelautan dan Perikanan Dumai, Riau \\ *Korespondensi: sadaharahap@gmail.com
}

\begin{abstract}
Fish sauce is a fermented product in the form of a dark brown liquid, it tastes relatively salty or sweet and smells good. The process of making fish sauce requires a long time. The proteolytic enzyme addition before fermentation can shorten the time in making fish sauce. The purpose of this study was to determine the fermentation process fish sauce from chicken feather by using enzymatic hydrolysis with pineapple juice, the effect of adding pineapple juice and fermentation time and to determine the results of the enzymatic organoleptic test and the most preferred by panelists. The method used in this research is an experimental quantitative method. Data analysis was done by using a completely randomized design (CRD). From the results of this study, the fermentation process of chicken feather fish sauce by adding different pineapple extract (25\%, 50\% and 75\%) from the weight of fish meat with fermentation time of 3 days, 6 days, 9 days, 12 days and 15. day. The analysis of the chicken feather fish sauce was done by using sensory (smell, taste, color and thickness). The best research results was obtained by increasing the concentration of pineapple extract by $25 \%$ at the fermentation time of 9 days with the criteria of unique, sweet flavor and brownish fish sauce that panelists like from the addition of a concentration of $25 \%$ pineapple extract at the fermentation time of 9 days in the fish sauce. This shows that the addition of pineapple juice extract can accelerate the fermentation process besides affecting the preferred hedonic value.
\end{abstract}

Keywords: Bromelain enzyme, Fermentation, Bulu ayam fish, Fishsauce

\section{Pendahuluan}

Ikan merupakan sumber protein hewani utama yang kaya akan protein dan mempunyai daya cerna mencapai $80 \%$. Sifat fisik ikan yang cepat mengalami pembusukan, khususnya pada iklim tropis dan kelembapan yang tinggi, maka perlu dilakukan pengawetan dan pengolahan salah satunya adalah melakukan fermentasi. Fermentasi ikan secara tradisional merupakan salah satu dari metode pengolahan yang mempunyai biaya rendah. Metode ini sudah banyak digunakan secara luas di Asia Tenggara, hasil fermentasi ikan dapat berupa kecap ikan (Isnawati, Sari, \& Sumarto, 2015).

Kecap merupakan suatu produk fermentasi yang berbentuk cairan berwarna coklat tua, rasanya relatif asin atau manis dan berbau sedap. Kecap biasanya dibuat dari sumber protein nabati maupun hewani secara hidrolisis asam maupun enzimatis (Fatriana, Ibrahim, \& Isamu, 2018). Kecap ikan merupakan salah satu produk perikanan tradisional yang diolah secara fermentasi dan telah dikenal sejak 
lama. Proses pembuatan kecap ikan membutuhkan waktu yang cukup lama. Secara tradisional kecap ikan dibuat dengan cara fermentasi menggunakan garam sebagai pengontrol mikroba. Proses fermentasi memerlukan kadar garam 20\% - 30\% dan memerlukan waktu fermentasi antara 6-12 bulan. Lamanya proses pembuatan kecap ikan menjadi kelemahan dalam proses produksi kecap ikan (Widyastuti, Riyadi, \& Ibrahim, 2014). Salah satu proses yang digunakan adalah menggunakan enzim untuk mempercepat proses fermentasi.

Rekayasa penambahan enzim proteolitik sebelum fermentasi dapat mempersingkat waktu pembuatan kecap ikan. Buah nanas mengandung enzim bromelin. Enzim bromelin merupakan bagian dari enzim proteolitik yang mampu memecah senyawa komplek menjadi senyawa lebih sederhana. Aktivitas bakteri asam laktat merupakan salah satu faktor penting dalam proses fermentasi. Bakteri asam laktat dapat menghasilkan senyawa bakteriosin yang menunjukkan aktivitas bakterisidal terhadap bakteri pathogen (Purwaningsih, 2017). Proses produksi kecap ikan biasanya menggunakan ikan spesies ikan kecil seperti Stolephorus sp., Sardinella sp., Rastrellinger sp., dan berbagai jenis ikan lainnya tergantung jenis daerah dan metode yang digunakan (Hounhouigan, Anihouvi, \& Kindossi, 2012). Namun penggunaan bahan baku yang berbeda dengan menggunakan metode yang berbeda dapat mempengaruhi sifat fisikokimia dari kecap ikan (Prasetyo, Sari dan Budiyati, 2012). Penelitian mengenai penambahan sari nanas pada pembuatan kecap ikan telah banyak dilakukan..

Dari penelitian terdahulu hanya meneliti tentang pengaruh konsentrasi pada pembuatan kecap ikan secara enzimatik dengan bahan baku yang berupa ikan besar seperti ikan tongkol dan ikan gabus. Dari latar belakang diatas maka peneliti tertarik untuk melakukan penelitian tentang pembuatan kecap ikan bulu ayam dengan menggunakan ekstrak sari nanas dengan variasi konsentrasi 25\%, 50\% dan $75 \%$ dan lama fermentasi 3,6,9,12 dan 15 hari terhadap hasil akhir kecap ikan yang dihasilkan.

Tujuan penelitian ini adalah untuk mengetahui proses fermentasi kecap ikan bulu ayam secara hidrolis enzimatis menggunakan sari nanas, pengaruh penambahan sari nanas dan lama fermentasi pada proses pembuatan kecap ikan dan menentukan hasil uji organoleptic kecap ikan bulu ayam secara enzimatis dan paling disukai panelis.

\section{Metode Penelitian}

Bahan baku yang digunakan dalam penelitian ini adalah ikan bulu ayam (Coilia dussumieri) yang merupakan ikan bernilai ekonomis rendah sebanyak $100 \mathrm{~g}$ untuk tiap sampelnya. Bahan penghidrolisisnya yaitu sari nanas yang mengandung enzim bromelin dan garam $\mathrm{NaCl}$ sebagai bahan pengawet pada produk kecap ikan. Konsentrasi sari nanas yang ditambahkan adalah 25, 50 dan 75\% (b/b). Konsentrasi garam $\mathrm{NaCl}$ yang digunakan yaitu $7 \%$ (b/b). Lama waktu hidrolisis yang diberikan adalah 3,6,9,12 dan 15 hari. Bahan tambahan lain yang digunakan dalam proses pembuatan kecap ikan diantaranya gula aren $30 \%$, serai $1 \mathrm{~cm}$, daun salam 2 lembar, 
lengkuas $1,3 \%$, bawang putih $1 \%$, kunyit $1 \%$, jahe $0,8 \%$ kayu manis $1 \%$ dan air $20 \%$. Diagram alir proses pembuatan kecap ikan dapat dilihat pada Gambar 1.

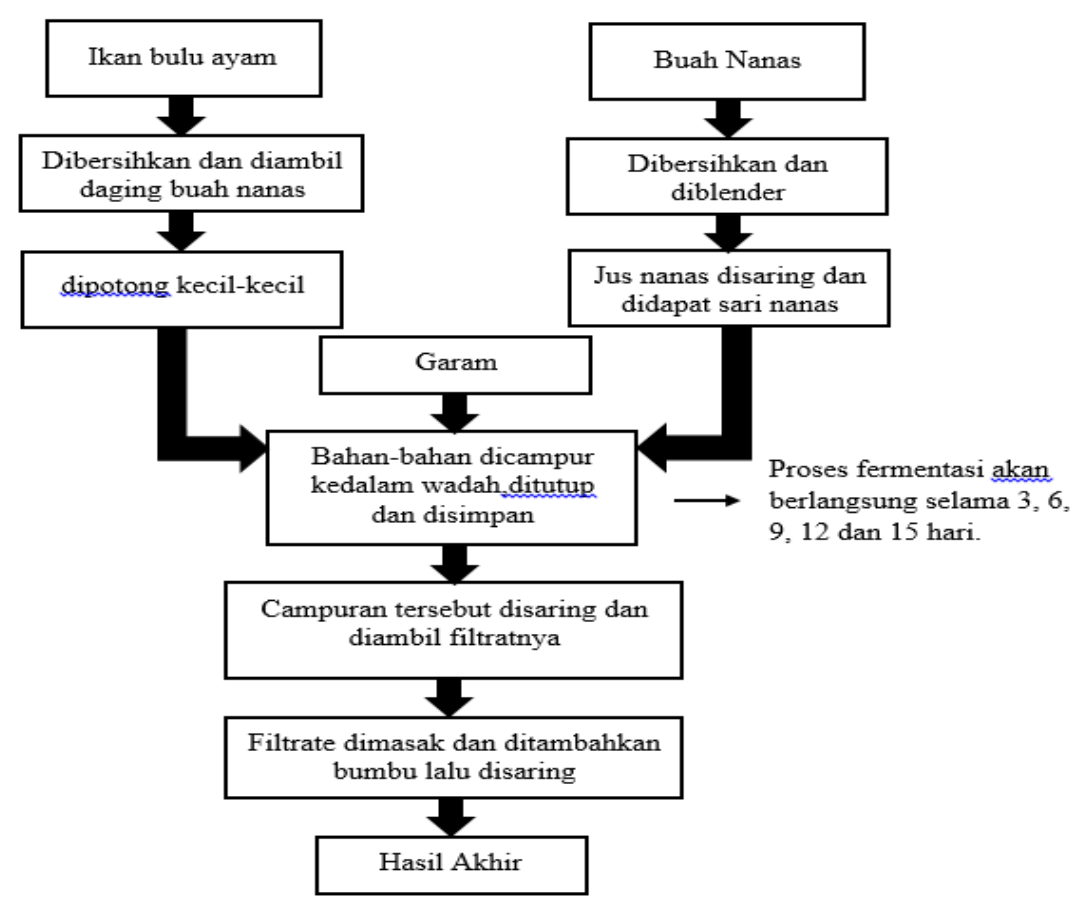

Gambar 1. Diagram Alir Proses Pembuatan Kecap Ikan

Parameter pengamatan pada penelitian ini terdiri dari karakteristik sensori meliputi yang meliputi pengujian aroma, rasa, warna dan kekentalan. Uji Sensori untuk kecap ikan dilakukan oleh panelis tidak terlatih sebanyak 30 orang yang merupakan masyarakat Bagansiapiapi. Parameter pengujian meliputi rasa, aroma, warna, dan kekentalan. Metode pengujian yang digunakan adalah metode hedonik (uji kesukaan) dengan skala 1-5 yaitu (1) sangat tidak suka, (2) tidak suka, (3) agak suka, (4) suka, (5) sangat suka. Perhitungan hasil uji sensori dilakukan dengan menggunakan rumus:

$$
\begin{aligned}
& P(x(1,96 . s / \sqrt{ } n)) \leq \mu \leq(x(1,96 . s / \sqrt{ } n))=95 \% \\
& X=\frac{\sum x i}{n} \\
& S^{2}=\frac{\sum(x-x)^{2}}{n} \\
& s=\sqrt{\frac{\sum(x-x)^{2}}{n}}
\end{aligned}
$$

Keterangan :

$\mathrm{n}$

s2

: Jumlah panelis

1,96

: Keragaman nilai mutu

$\mathrm{X}$

: Koefesien standar deviasi pada taraf $95 \%$

$\mathrm{Xi}$

: Nilai mutu rata-rata

$\mathrm{S}$

: Nilai mutu dari penelis ke I, dimana $\mathrm{i}=1,2,3 \ldots \ldots \mathrm{n}$;

: Simpangan baku nilai mutu 
Analisa data selanjutnya dilakukan uji $\mathrm{F}$ (pengujian secara simultan). Pengujian ini dilakukan untuk mengetahui pengaruh variable independen yang terdapat didalam mode secara bersama sama (simultan) terhadap variable dependen uji $\mathrm{F}$ dalam penelitian ini digunakan untuk menguji segnifikan pengaruh penambahan ekstrak sari nanas dan lama fermentasi terhadap tingkat kesukaan panelis berdasarkan tiap parameter secara simultan. $\mathrm{F}$ hasil perhitungan ini dibandingkan dengan Ftabel yang diperoleh dengan menggunakan tingkat resiko atau signifikan level 5\% dan 1\% dengan kriteria sebagai berikut:

$\mathrm{H} 0$ ditolak jika Fhitung $>$ Ftabel atau nilai sig $<" \alpha "$

$\mathrm{H} 0$ diterima jika Fhitung $<$ Ftabel atau nilai sig $>$ " $\alpha$ "

\section{Hasil dan Pembahasan}

Uji Sensori

Hasil pembuatan kecap ikan bulu ayam (Coilia dussumieri) dengan berbagai konsentrasi ekstrak sari nanas dan lama fermentasi kemudian dilakukan pengujian sensori. Uji sensori atau uji indra merupakan cara pengujian dengan menggunakan indra manusia sebagai alat utama untuk pengukuran daya penerimaan terhadap suatu produk (Suryono, Ningrum, \& Dewi, 2018). Parameter yang diuji meliputi aroma, rasa, warna dan kesukaan dengan menggunakan skala mutu hedonik. Uji hedonik merupakan pengujian yang paling banyak digunakan untuk menguji tingkat kesukaan panelis terhadap suatu produk misalnya sangat suka,suka, agak suka, agak tidak suka, tidak suka dan sangat tidak suka. Data yang diperoleh selanjutnya ditabulasi dan dihitung dengan menggunakan rumus perhitungan uji hedonik (SNI 01-2346-2011) untuk mengetahui interval mutu kecap ikan. Hasil perhitungan uji sensori dapat dilihat pada Tabel 1.

Tabel 1. Hasil Perhitungan Uji Sensori

\begin{tabular}{lccccccccccccccc}
\hline \multirow{2}{*}{ Parameter } & N1 & N2 & N3 & N1 & N2 & N3 & N1 & N2 & N3 & N1 & N2 & N3 & N1 & N2 & N3 \\
& F1 & F1 & F1 & F2 & F2 & F2 & F3 & F3 & F3 & F4 & F4 & F4 & F5 & F5 & F5 \\
\hline Warna & 3 & 2 & 2 & 2 & 2 & 3 & 3 & 3 & 3 & 2 & 1 & 3 & 2 & 3 & 3 \\
Rasa & 2 & 3 & 2 & 2 & 2 & 3 & 3 & 2 & 2 & 3 & 2 & 3 & 2 & 2 & 4 \\
Aroma & 2 & 3 & 2 & 2 & 2 & 2 & 2 & 2 & 2 & 4 & 2 & 3 & 2 & 3 & 2 \\
Kekentalan & 3 & 2 & 2 & 3 & 2 & 3 & 3 & 2 & 3 & 5 & 1 & 2 & 2 & 2 & 1
\end{tabular}

Berdasarkan tabel 1 dapat dilihat hasil perhitungan sampel N1F4 menunjukkan nilai warna (2), rasa (3), aroma (4) dan kekentalan (3). Yang menunjukkan rata-rata lebih besar dibandingkan sampel yang lain. Berdasarkan SNI kecap ikan (SNI 014271-1996) bahwa kecap ikan dengan penambahan sari nanas $25 \%$ dan lama fermentasi 9 hari yang paling sesuai spesifikasi yaitu rasa dan aroma yang khas serta warna yang normal. Hal ini berarti tidak semua perlakuan penambahan ekstrak sari nanas dan lama fermentasi menghasilkan hasil yang sesuai dengan yang diharapkan. Kecap ikan dengan penambahan eksrtak sari nanas 25\% dengan fermentasi 3 hari akan menghasilkan aroma dan rasa yang tidak disukai panelis 
sementara penambahan ekstrak sari nanas $75 \%$ dan lama fermentasi 15 hari akan menghasilkan kekentalan dan aroma yang tidak disukai panelis.

\section{Aroma}

Aroma merupakan nilai tambah dalam suatu produk, dengan mencium aroma seseorang dapat mengenal enaknya suatu produk. Aroma merupakan parameter penting dalam pengujian organoleptik kecap ikan. Aroma kecap ikan cenderung khas. . Pada penelitian ini aroma kecap ikan cenderung beraroma rempah-rempah. Maliha, Affrianto, Buwono, \& Rostini (2018) menyatakan bahwa penambahan jahe yang tidak terlalu banyak dapat mempengaruhi aroma pada kecap dikarenakan aroma jahe yang tajam. Aroma yang terkandung dalam jahe berupa senyawa oleoresin yang khas (Saptiwi, Sunarjo, \& Rahmawati, 2018). Hal ini dikarenakan penambahan rempah-rempah untuk mengurangi aroma kecap ikan. Hasil uji sensori menunjukkan bahwa perlakuan konsentrasi ekstrak sari nanas pada variasi fermentasi 9 hari $25 \%$ lebih dominan disukai panelis.

Tabel 2. Nilai Aroma Hasil Uji F

\begin{tabular}{lcllllll}
\hline \multicolumn{1}{c}{ SK } & DB & JK & KT & $\begin{array}{c}\text { F } \\
\text { HITUNG }\end{array}$ & F TABEL & KETERANGAN \\
\hline Sampel & 14 & 117 & 8.34 & & $5 \%$ & $1 \%$ & \\
Panelis & 29 & 29.6 & 1.02 & 9.31 & & & \\
Galat & 406 & 364 & 0.9 & & 1.71 & 2.11 & Berbeda sangat nyata \\
Total & 449 & 510 & \multicolumn{5}{l}{} \\
\multicolumn{5}{l}{ Keterangan: DB(derajat bebas), JK(jumlah kuadrat), KT(kuadrat tengah sampel) }
\end{tabular}

Berdasarkan tabel 2. Dapat dilihat hasil perhitungan uji F menunjukkan bahwa nilai $F_{\text {hitung }}$ (9.31)lebih besar dari $F_{\text {Tabel }}$ (2.11). Hal ini mengidentifikasikan bahwa perbedaan konsentrasi ektrak sari nanas dan lama fermentasi memberikan perngaruh yang berbeda sangat nyata pada tingkat kesukaan panelis terhadap aroma kecap ikan.

\section{Rasa}

Rasa merupakan tanggapan indra terhadap saraf, seperti manis, pahit, sama dan asin. Rasa suatu produk berpengaruh terhadap kesukaan seseorang. Kecap ikan pada umumnya memiliki rasa asin dan sedikit pahit yang disebabkan oleh adanya pemecahan protein ikan. Rasa asin yang terdapat pada kecap ikan dapat timbul dengan adanya penambahan garam dalam proses fermentasi (Widyastuti, Riyadi, \& Ibrahim, 2014). Kecap ikan bulu ayam dibuat dengan penambahan konsentrasi nanas yang berbeda sehingga menghasilkan karakteristik yang berbeda. Garam dapat mengurangi rasa pahit dan sebagai bahan pengawet. Hasil perhitungan uji $\mathrm{F}$ dapat dilihat pada Tabel 3. 


\begin{tabular}{lcccccccc}
\hline \multicolumn{1}{l}{ Tabel 3. Nilai Rasa Hasil Uji F } & & & & \\
\hline \multicolumn{1}{c}{ SK } & DB & JK & KT & $\begin{array}{c}\text { F } \\
\text { HITUNG }\end{array}$ & F TABEL & KETERANGAN \\
\hline Sampel & 14 & 54.9 & 3.92 & & $5 \%$ & $1 \%$ & & \\
Panelis & 29 & 24.8 & 0.85 & 3.91 & 1.71 & 2.11 & $\begin{array}{l}\text { Berbeda } \\
\text { nyata }\end{array}$ & sangat \\
Galat & 406 & 406 & 1 & & & & nyata \\
Total & 449 & 486 & & & &
\end{tabular}

Keterangan: DB(derajat bebas), JK(jumlah kuadrat), KT(kuadrat tengah sampel)

Hasil perhitungan uji hedonik kecap ikan bulu ayam menunjukkan kecap ikan dengan konsentrasi ekstrak sari nanas $75 \%$ dengan lama fermentasi 15 hari merupakan kecap ikan dengan formulasi yang disukai panelis. Kecap ikan dengan konsentrasi ini mengandung banyak sari nanas. Rasa dapat berpengaruh pada penambahan gula aren untuk mengurangi rasa pahit. Selain itu fermentasi selama 15 hari menyebabkan ikan menjadi hancur bahkan hanya tersisa tulang ikan. Hasil uji $\mathrm{F}$ menunjukkan $F_{\text {hitung }}$ lebih besar dari $F_{\text {tabel }}$ sehingga dapat diidentifikasikan bahwa perbedaan konsentrasi ektrak sari nanas dan lama fermentasi memberikan perngaruh yang berbeda sangat nyata pada tingkat kesukaan panelis terhadap rasa kecap ikan.

\section{Warna}

Warna merupakan hal yang penting bagi banyak makanan dan warna juga memberikan petunjuk mengenali perubahan kimia dalam makanan. Warna kecap ikan pada umumnya berwarna bening (SNI 01-2346-2011). Kecap ikan yang belum melalui proses pemasakan memiliki warna yang beragam diantaranya bening, kecoklatan bahkan hingga keruh. Berdasarkan tabel persyaratan mutu menurut SNI kecap ikan (SNI 01-4271-1996) bahwa warna kecap ikan normal artinya dapat berwarna coklat terang hingga coklat tua tergantung bahan baku dan metode pengolahan yang digunakan. Kecap ikan yang telah melalui proses pemasakan memiliki warna kecoklatan pekat. Warna kecoklatan pada kecap ikan dapat terjadi pada saat proses fermentasi karena adanya reaksi mailard (Widyastuti, Riyadi, \& Ibrahim, 2014). Warna kecoklatan pada kecap ikan setelah proses pemasakan dapat disebabkan oleh adanya karamelisasi oleh gula aren.

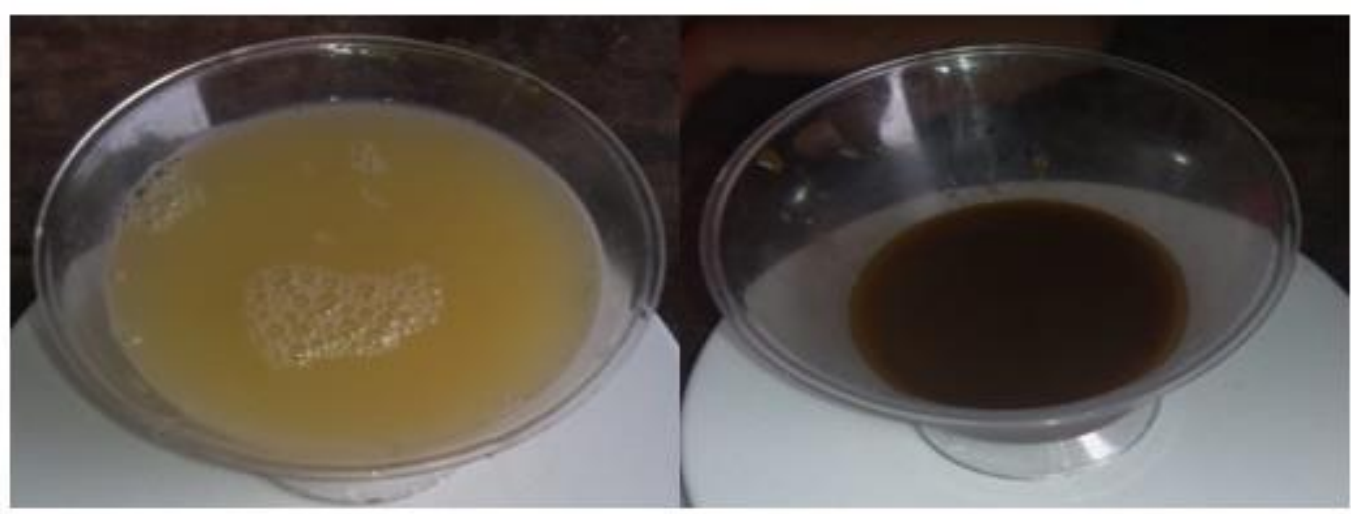

(a) (b)

Gambar 2. Perbandingan kecap ikan sebelum (a) dan setelah proses pemasakan

(b) 
Berdasarkan Gambar 2 dapat dilihat perbedaan kecap ikan sebelum proses pemasakan dan setelah proses pemasakan. Kecap ikan sebelum proses pemasakan berwarna kuning seperti ekstrak sari nanas. Kecap ikan yang telah mengalami proses pemasakan berwarna pekat, selain warna pekat volume kecap ikan juga menjadi berkurang. Kecap ikan sebelum proses pemasakan lebih cair dengan aroma yang pekat. Kecap ikan setelah mengalami proses pemasakan cenderung kental dan memiliki aroma rempah yang khas. Berdasarkan hasil penelitian, uji nilai warna yang dilakukan oleh 30 panelis tidak terlatih terhadap mutu kecap ikan bulu ayam dengan penambahan ekstrak sari nanas yang berbeda dapat dilihat pada Tabel 4.

Tabel 4. Nilai Warna Hasil Uji F

\begin{tabular}{lcccccccc}
\multicolumn{1}{c}{ SK } & DB & JK & KT & $\begin{array}{c}\text { F } \\
\text { HITUNG }\end{array}$ & F TABEL & KETERANGAN \\
\hline Sampel & 14 & 49.1 & 3.51 & & $5 \%$ & $1 \%$ & \\
Panelis & 29 & 35.1 & 1.21 & 2.77 & & & Berbeda & sangat \\
Galat & 406 & 514 & 2.26 & & 1.71 & 2.11 & nyata & \\
Total & 449 & 598 & \multicolumn{7}{c}{} & & \\
Keterangan: DB(derajat bebas), JK(jumlah kuadrat), KT(kuadrat tengah sampel) &
\end{tabular}

Berdasarkan hasil analisis uji F dapat dijelaskan bahwa kecap ikan bulu ayam dengan penambahan ekstrak sari nanas dan lama fermentasi berpengaruh nyata terhadap nilai warna, dimana Fhitung $(2,77)>$ Ftabel $(2,11)$ pada tingkat kepercayaan 95\% yang berarti hipotesis (H0) ditolak. Hasil perhitungan kecap ikan dengan menggunakan metode hedonik menunjukkan nilai antara 2 hingga 3 pada kecap ikan yang berbeda (Lampiran 3). Ini menunjukkan panelis tidak terlalu menyukai warna dari kecap ikan yang dihasilkan. Hal ini dapat dipicu karena adanya pengendapan pada kecap ikan yang dapat merusak warna karena endapan kecap ikan berwarna coklat muda dari pada kecap ikan yang memiliki warna coklat tua hal ini sesuai dengan pendapat Oktaviani, Rahayu, \& Suhartatik (2015) yang menyatakan bahwa semakin lama fermentasi dan semakin banyak konsentrasi ekstrak sari nanas yang ditambahkan maka warna kecap ikan lele yang dihasilkan tidak jernih.

\section{Kekentalan}

Kekentalan kecap ikan mempengaruhi kenampakan pada kecap ikan. Kecap ikan dapat mengental disebabkan penambahan gula aren dan proses pemanasan diatas api sedang selama 5 menit. Dari hasil perhitungan menunjukkan beberapa panelis tidak menyukai kecap yang cenderung encer seperti kecap ikan dengan konsentrasi $75 \%$ dan lama fermentasi 15 hari (Lampiran 3). Kecap ikan ini memiliki sifat yang sangat encer dikarenakan mengandung banyak air hasil ekstrak sari nanas, selain itu lamanya fermentasi dapat menyebabkan air dalam kecap ikan bertambah. Kecap ikan dengan kandungan yang kental cenderung disukai panelis diantaranya kecap ikan dengan kode sampel N1F1, N1F2, N3F3 dan N1F4. 


\begin{tabular}{lccllllll}
\hline \multicolumn{7}{l}{ Tabel 5. Nilai Kekentalan Hasil Uji F } \\
\hline SK & DB & JK & KT & $\begin{array}{c}\text { F } \\
\text { HITUNG }\end{array}$ & F TABEL & KETERANGAN \\
\hline Sampel & 14 & 99.6 & 7.11 & & $5 \%$ & $1 \%$ & & \\
Panelis & 29 & 17.5 & 0.6 & 13.67 & 1.71 & 2.11 & $\begin{array}{l}\text { Berbeda } \\
\text { nyata }\end{array}$ & sangat \\
Galat & 406 & 211 & 0.52 & & & & & \\
Total & 449 & 328 & & & & & \\
Keterangan: DB(derajat bebas), JK(jumlah kuadrat), KT(kuadrat tengah sampel)
\end{tabular}

Hasil perhitungan uji F menunjukkan bahwa nilai Fhitung (13.67) lebih besar dari FTabel (2.11). hal ini mengidentifikasikan bahwa perbedaan konsentrasi ektrak sari nanas dan lama fermentasi memberikan pengaruh yang berbeda sangat nyata pada tingkat kesukaan panelis terhadap kekentalan kecap ikan. Hal ini dapat disebabkan oleh metode pengolahan kecap ikan dan bahan yang dicampurkan berbeda dengan kecap ikan pada umumnya sehingga menghasilkan kecap ikan yang berbeda.

\section{Kesimpulan}

Pembuatan kecap ikan bulu ayam secara hidrolisis enzimatis menggunakan sari nanas dapat dilakukan dengan melalui beberapa tahapan proses yaitu pembersihan ikan dan nanas, pembuatan ektrak sari nanas, pemotongan ikan, penambahan garam kemedia, fermentasi, dan penyaringan. Pengaruh penambahan ekstrak sari nanas dapat mempercepat proses fermentasi selain itu berpengaruh terhadap nilai hedonik yang disukai. Hasil uji F penerimaan keseluruhan produk pada kecap ikan bulu ayam memperlihatkan bahwa terdapat perbedaan yang sangat nyata antar perlakuan. Hasil penilaian organoleptik kecap ikan berkisar antara 1 (sangat tidak suka) hingga 4 (suka). Produk terbaik yang dihasilkan dari hasil pengujian organoleptik adalah kecap ikan bulu ayam dengan lama fermentasi 9 hari pada konsentrasi ekstrak sari nanas $25 \%$.

\section{Ucapan Terimakasih}

Terima kasih penulis ucapkan kepada Direktur Politeknik Kelautan dan Perikanan Dumai yang telah memberikan bantuan dana dukungan dan kesempatan kepada penulis untuk melaksanakan penelitian ini.

\section{Daftar Pustaka}

[BSN] Badan Standardisasi Nasional. 2011. Pedoman Pengujian Sensori Pada Produk Perikanan. SNI 01-2346-2011. BSN.Jakarta.

Fatriana, Y., Ibrahim, M. N., \& Isamu, K. T. 2018. Pengaruh perbandingan daging kerang pokea Batissa violacea var. celebensis, von martens 1897 dan buah nanas (Ananas comosus) terhadap kualitas kecap. JFP, 1(1), 48-57.

Hounhouigan, J. D., Anihouvi, V. B., \& Kindossi, J. M. 2012. Processing and quality characteristics of some major fermented fish products from Africa Anihouvi VBProcessing and quality characteristics of some major fermented fish products from Africa. Journal of Biological Sciences, 1(7), 72-84. 
Isnawati, Sari, N. I., \& Sumarto. 2015. Pengaruh penambahan volume sari nanas yang berbeda terhadap mutu kecap ikan gabus (channa striata). JOM, 1-10.

Maliha, D., Affrianto, E., Buwono, I. D., \& Rostini, I. 2018. Penambahan Jahe Sebagai Flavor Dalam Pembuatan Kecap Udang Putih Secara Fermentasi Enzimatis. Jurnal Perikanan dan Kelautan, 9(1), 81-87.

Oktaviani, R., Rahayu, K., \& Suhartatik, N. 2014. Pemanfaatan limbah nanas (Ananas comosus L. Merr) pada pembuatan kecap ikan lele (Clarias sp) dengan variasi lama fermentasi. Jurnal Teknologi dan Industri Pangan, 1(2), 134-144.

Prasetyo, M. N., Sari, N., \& Budiyati, S. 2012. Pembuatan kecap Dari Ikan Gabus Secara Hidrolisis Enzimatis Menggunakan Sari Nanas. Jurnal Teknologi Kimia dan Industri, (1), 329-337.

Purwaningsih, I. 2017. Potensi enzim bromelin sari buah nanas (Ananas comosus 1.) dalam meningkatkan kadar protein pada tahu. Jurnal Teknologi Laboratorium, 6(1), 39-46.

Saptiwi, B., Sunarjo, L., \& Rahmawati, H. 2018. Perasan Jahe Merah (Zingiber Oficinale Var.Rubrum) Terhadap Daya Hambat Bakteri Aggregatibacter Actinomycetemcomitans. Jurnal Riset Kesehatan, 7(2), 61-65.

Suryono, C., Ningrum, L., \& Dewi, T. R. 2018. Uji Kesukaan dan Organoleptik Terhadap 5 Kemasan Dan Produk Kepulauan Seribu Secara Deksriptif. Jurnal Pariwisata, 5(2), 95-106.

Widyastuti, P., Riyadi, P. H., \& Ibrahim, R. 2014. Mutu kecap ikan yang terbuat dari isi perut ikan manyung (Arius thalassinus) dengan konsentrasi garam yang berbeda. Jurnal Saintek Perikanan, 9(2), 18-23. 